\title{
BUDI DAYA UDANG WINDU PADA TAMBAK POLA RESIRKULASI MENGGUNAKAN SISTEM TANDON
}

\author{
Gunarto, Muslimin, dan Abdul Mansyur
}

\begin{abstract}
ABSTRAK
Untuk menjaga agar kondisi perairan tambak budi daya udang tetap baik, maka sistem biofilter dan resirkulasi digunakan dalam penelitian ini. Tujuan penelitian adalah untuk mengetahui produksi udang windu pada padat tebar udang yang berbeda dan juga tinjauan terhadap mutu kualitas airnya pada budi daya udang windu pola resirkulasi air semi tertutup menggunakan sistem tandon. Penelitian dilaksanakan di Tambak Maranak menggunakan 12 petak masingmasing ukuran $500 \mathrm{~m}^{2}$. Padat tebar udang windu yang diuji adalah 4 (A) ,6 (B), dan 8 ekor/m² (C). masing-masing perlakuan dengan 4 ulangan. Pengelolaan air dalam tambak menggunakan pola resirkulasi dengan sistem tandon bakau. Parameter kualitas air yang diamati adalah suhu, oksigen terlarut, bahan organik total (BOT), $\mathrm{NH}_{4}-\mathrm{N}, \mathrm{NO}_{3}-\mathrm{N}, \mathrm{NO}_{2}-\mathrm{N}, \mathrm{PO}_{4}-\mathrm{P}$, indeks keragaman plankton, kandungan total bakteri Vibrio sp. pada air dan sedimen, serta produksi udang. Hasil penelitian menunjukkan bahwa sisa pakan dan sisa metabolisme udang menyebabkan meningkatnya akumulasi BOT di ketiga tambak perlakuan dan menunjukkan perbedaan yang tidak berarti $(P>0,05)$. Kandungan amonia total meskipun sudah ada input pakan ke dalam tambak, konsentrasi amonia terus menurun hingga hari ke-70. Berdasarkan nilai indeks keragaman plankton terdapat variasi jumlah puncak-puncak nilai indeks diversitas plankton. Populasi bakteri Vibrio sp. nampak terjadi peningkatan di semua petak tambak perlakuan $(P>0,05)$ dan belum membahayakan bagi udang di tambak. Produksi udang di perlakuan $B$ tertinggi dibanding perlakuan lainnya yaitu $20,8 \mathrm{~kg} / 500 \mathrm{~m}^{2}$.
\end{abstract}

\begin{abstract}
The tiger shrimp culture in semi-closes recirculation systems pond using reservoir. By: Gunarto, Muslimin, and Abdul Mansyur

To keep the pond water in healthy condition, biofilters and recirculation systems were used in this research. The objective of this research is to know the shrimp production in different stocking densities of tiger shrimp cultured in brackishwater pond and to observe the water quality in brackishwater pond using semi-closed recirculation system with pond reservoirs. The research conducted in Maranak Pond station using 12 pond compartments each size of $500 \mathrm{~m}^{2}$. The different shrimp stocking densities were tested in pond i.e. $4(A), 6(B)$ and 8 pcs. $/ \mathrm{m}^{2}(C)$, each treatment with four replications. The recirculation and reservoir systems were used for water quality management in pond. Some water quality parameters monitored were including water temperature, dissolved oxygen, total organic matter (TOM), $\mathrm{NH}_{4}-\mathrm{N}, \mathrm{NO}_{3}-\mathrm{N}, \mathrm{NO}_{2}-\mathrm{N}, \mathrm{PO}_{4}-\mathrm{P}$, plankton indices diversity, total Vibrio sp. bacterial content in the water as well as in the sediment. The results of this research showed increasing of TOM accumulation in all the three pond treatments and statistically were not significantly different $(P>0.05)$. Total ammonium was decreasing until at day 70 , even though feed was given to the shrimp in pond. Based on the plankton indices diversity, there was varies of total peaks of plankton indices diversity value among three treatments. The Vibrio $s p$. population in all treatment pond showed the increasing, however statistically were not significantly different $(P>0.05)$ and were still undangerous to the shrimp in pond. The highest shrimp production $\left(20.8 \mathrm{~kg} / 500 \mathrm{~m}^{2}\right)$ was obtained in treatment $B$
\end{abstract}

KEYWORDS: culture, recirculation, reservoir

\section{PENDAHULUAN}

Mutu air yang optimum selama proses budi daya diharapkan mampu menanggulangi berjangkitnya penyakit udang, sehingga bisa mengurangi risiko kegagalan panen udang dari hasil budi daya di tambak. Untuk menjaga agar kondisi perairan tambak budi daya udang tetap baik, maka berbagai upaya telah dilakukan di antaranya menggunakan sistem biofilter dan resirkulasi (Atmomarsono et al., 1995; Mangampa et al., 1997; Mangampa, 1998). Dilaporkan pula bahwa mangrove selain dapat menstabilkan konsentrasi $\mathrm{NO}_{3}-\mathrm{N}$ dan $\mathrm{PO}_{4}-\mathrm{P}$ juga mampu menghambat pertumbuhan Vibrio spp., selain itu mangrove juga mampu menjebak dan mendaur ulang berbagai bahan organik, logam berat, dan bahan kimia

Peneliti pada Balai Riset Perikanan Budidaya Air Payau, Maros 
lain. Organisme yang menempel di akar mangrove juga berfungsi sebagai biofilter (Ahmad, 1999).

Dalam budi daya udang semi intensif maupun intensif input pakan yang diberikan ke udang tidak semuanya habis dimakan, sisa pakan dan sisa metabolisme udang dapat menyebabkan parameter kualitas air tambak tidak layak lagi untuk hidupnya udang, misalnya kelebihan nutrien yang bisa menyebabkan eutrofikasi, ataupun kelebihan bahan organik diduga bisa menyebabkan mewabahnya penyakit baik yang ditimbulkan oleh bakteri seperti Vibrio harveyi maupun oleh virus WSSV (Atmomarsono, 2003).

Introduksi bandeng dan tiram di tandon mangrove diharapkan akan lebih mengefektifkan fungsi biofilter mangrove. Tiram adalah organisme filter feeder yang dapat memanfaatkan kelebihan plankton, bahan organik, jamur, dan flagellata sebagai makanannya (Imai, 1971). Menurut Walne (1972), tiram mampu memfilter air sebanyak $10 \mathrm{~L} / \mathrm{jam}$. Dengan introduksi tiram dan bandeng dalam tandon mangrove yang digunakan sebagai biofilter, kemudian air dialirkan masuk ke petak tandon yang diperkaya dengan Gracillaria sp., maka petak tersebut sekaligus sebagai petak pengendapan dan petak biofilter. Gracillaria sp. diharapkan dapat berperan untuk menyerap kelebihan amonia dan fosfat yang berasal dari hasil penguraian sisa pakan. Menurut Neori et al. (1996), jenis rumput laut Ulva lactuca dapat menyerap 50\% amonia yang berasal dari hasil penguraian bahan organik dari sisa pakan. Selanjutnya Troell et al. (1999) melaporkan bahwa Gracillaria sp. mampu menyerap 50\% amonia yang terlarut di air yang dilepaskan oleh ikan. Gunarto et al. (2003) mendapatkan antara 29\% - 34\% amonia yang dikeluarkan oleh benur dan dari hasil penguraian sisa pakan yang diserap oleh rumput laut Gracillaria sp.

Terdapat indikasi bahwa keberadaan tandon yang diisi bandeng mampu menurunkan kandungan BOT air yang akan digunakan dalam budi daya udang windu (Gunarto et al., 2002). Perbaikan dari pola resirkulasi dan sistem budi daya diharapkan akan lebih mengefektifkan fungsi biofilter yang pada akhirnya mampu memperbaiki kualitas air untuk budi daya udang.

Tujuan penelitian adalah untuk mengetahui padat tebar udang windu yang paling tepat ditinjau dari kualitas air dan produksinya pada budi daya udang menggunakan pola resirkulasi air semi tertutup dengan sistem tandon.

\section{BAHAN DAN METODE}

Penelitian dengan pola Rancangan Acak Lengkap (RAL) dilaksanakan di Instalasi Tambak Penelitian Maranak menggunakan tambak ukuran $500 \mathrm{~m}^{2}$ sebanyak 12 unit, dan satu unit tandon mangrove $\left(2000 \mathrm{~m}^{2}\right)$, serta tiga unit petak tandon masing-masing ukuran $500 \mathrm{~m}^{2}$ (tandon I), $500 \mathrm{~m}^{2}$ (tandon II ) dan 800 $\mathrm{m}^{2}$ (tandon III). Petak mangrove ditebari dengan tiram $1.000 \mathrm{~kg}$ dipelihara dengan sistem rak di depan pintu air, di petak mangrove juga ditebar gelondongan bandeng sebanyak 1.000 ekor. Petak tandon I ditebari rumput laut Gracillaria sp. sebanyak $500 \mathrm{~kg} / 500 \mathrm{~m}^{2}$ Petak tandon ke-Il ditebari gelondongan bandeng ukuran 3-5 g dengan kepadatan 2.500 ekor $/ 500 \mathrm{~m}^{2}$, petak tandon ke-III yaitu tandon pembuangan juga ditebari bandeng dengan kepadatan 2.500 ekor/ 800 $\mathrm{m}^{2}$ dan rumput laut Gracillaria sp. sebanyak $500 \mathrm{~kg} /$ $800 \mathrm{~m}^{2}$. Persiapan tambak untuk penebaran sesuai prosedur pembesaran udang windu di tambak meliputi pengeringan, kedok teplok (pengangkatan lumpur dasar tambak), pengolahan tanah dasar, pengapuran, pemberantasan hama, dan pemupukan.

Tokolan benur $P L-40$ dengan ukuran yang seragam ditebar dalam tambak pola resirkulasi semi tertutup, aliran air dimulai dari air sungai kemudian dimasukkan ke petak tandon mangrove, kemudian air dialirkan ke tandon Gracilaria sp., selanjutnya air dimasukkan ke tandon bandeng, baru kemudian air dimasukkan ke petak udang. Perlakuan yang diuji adalah padat tebar udang yaitu 4,6 , dan 8 ekor $/ \mathrm{m}^{2}$, masing-masing perlakuan dengan 4 ulangan

Tinggi air dalam tambak pemeliharaan dijaga pada kedalaman $80-90 \mathrm{~cm}$ terutama pada saat pasang, sedangkan saat surut (konda) tinggi air turun sampai $50 \mathrm{~cm}$. Penggantian air dalam petak udang sebanyak $10 \%-15 \%$ terutama dilakukan pada saat air pasang, air buangan dari petak udang, masuk ke tambak tandon pembuangan dalam beberapa hari dan selanjutnya air di alirkan ke petak mangrove. Model pengelolaan air dilakukan secara sirkulasi semi tertutup (Gambar 1)

Udang diberikan pakan dimulai dua minggu setelah penebaran sebanyak $10 \%$ dari bobot biomassa/hari. Selanjutnya pada bulan berikutnya pakan yang diberikan 5\%-3\% total biomassa/hari, disesuaikan dengan bobot udang dan nafsu makan udang berdasarkan sampling secara rutin setiap dua minggu sekali (Mangampa \& Mustafa, 1992).

Sampling kualitas air dilakukan setiap dua minggu meliputi salinitas diukur dengan refraktometer, suhu dan kandungan oksigen diukur dengan $\mathrm{DO}$ meter, dan $\mathrm{NH}_{3}-\mathrm{N}, \mathrm{NO}_{2}-\mathrm{N}, \mathrm{NO}_{3}-\mathrm{N}, \mathrm{PO}_{4}-\mathrm{P}, \mathrm{pH}$, dan BOT dianalisis berdasarkan prosedur dari Parson et al. (1984). Sampling kualitas air, total bakteri, dan plankton dilakukan sebelum penggantian air pada petak tambak, petak tandon mangrove, tandon rumput laut tandon bandeng, dan tandon pembuangan. Juga dilakukan sampling plankton di petak tambak. 


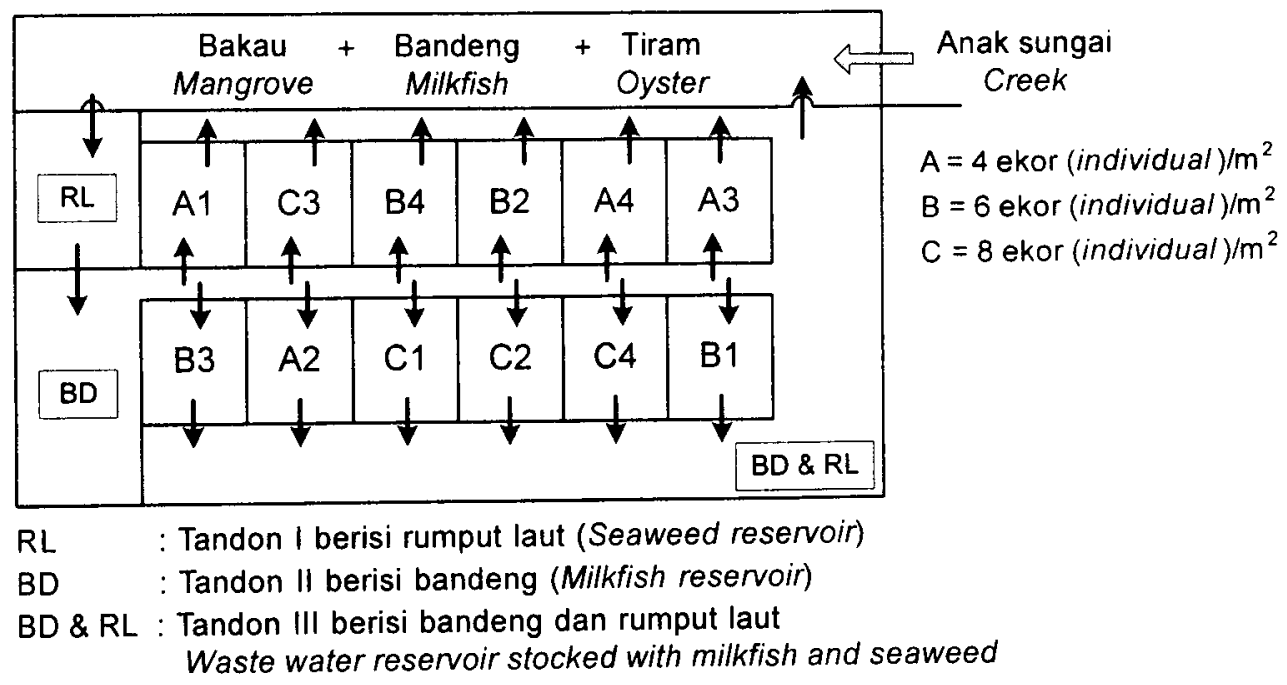

Gambar 1. Pola resirkulasi air pada pemeliharaan udang di tambak dengan padat tebar berbeda

Figure 1. The scheme of water recirculation system in shrimp pond cultured at the different stocking densities

Pengambilan plankton dilakukan dengan penyaringan menggunakan plankton net mesh size 40 mikron. Komposisi fitoplankton dan zooplankton diidentifikasi berdasarkan kunci dari Yama (1966); Newel \& Newel (1987). Indeks keragaman plankton yang dapat mengindikasikan kestabilan ekosistem tambak dihitung berdasarkan rumus Shanon-Wiener (Kreb, 1978 dalam Odum, 1963).

Indeks Keragaman Jenis:

$$
\begin{aligned}
& \mathrm{H}^{\prime}=-\Sigma \mathrm{Pi} \log _{2} \mathrm{Pi} \\
& \mathrm{Pi}=\frac{\mathrm{ni}}{\mathrm{N}}
\end{aligned}
$$

\footnotetext{
$H^{\prime}=$ Indeks keragaman jenis

$\mathrm{ni}=$ Jumlah individu taksa ke $\mathrm{i}$

$\mathrm{N}=$ Jumlah total individu
}

Data kualitas air yang diperoleh kemudian dibuat grafik. Untuk melihat pengaruh perlakuan terhadap kualitas air tambak perlakuan, maka data yang diperoleh dianalisis menggunakan analisis varians dengan bantuan perangkat lunak SPSS for windows. Data produksi, sintasan, dan konversi pakan dianalisis secara deskriptif karena yang mempunyai ulangan hanya perlakuan $A$, sedangkan pada perlakuan $B$ dan $C$ tidak mempunyai ulangan yaitu masing-masing hanya satu petak, karena udangnya semua mati akibat terserang WSSV.

\section{HASIL DAN BAHASAN}

Pada awalnya masing-masing perlakuan dengan 4 ulangan, namun akibat serangan WSSV yang menyebabkan kematian udang secara massal, maka hingga hari ke-70 pemeliharaan, masing-masing perlakuan tinggal dengan dua ulangan. Pada hari ke-70 ukuran udang relatif berbeda di mana pada padat tebar yang lebih rendah rata-rata ukuran udang relatif lebih besar daripada ukuran udang pada kepadatan yang lebih tinggi, yaitu rata-rata $12,05 \mathrm{~g}$ $\left(\mathrm{A}=4 \mathrm{ekor} / \mathrm{m}^{2}\right) ; 9,55 \mathrm{~g}\left(\mathrm{~B}=6 \mathrm{ekor} / \mathrm{m}^{2}\right) ;$ dan $8,4 \mathrm{~g}(\mathrm{C}=$ $\left.8 \mathrm{ekor} / \mathrm{m}^{2}\right)$, namun secara statistik rata-rata bobot udang tersebut menunjukkan perbedaan yang tidak berarti $(P>0,05)$. Produksi, sintasan, dan konversi pakan udang dapat diketahui setelah udang dipanen. Oleh karena WSSV terus menyerang udang yang dipelihara di tambak, maka sampai hari ke-91 yang bisa dipanen hanya 2 petak perlakuan $A, 1$ petak perlakuan $B$ dan 1 petak perlakuan $C$ yang juga sudah terserang WSSV dalam waktu 5 hari. Data yang diperoleh dapat dilihat pada Tabel 1, yang memperlihatkan bahwa sampai 91 hari pemeliharaan perlakuan B $\left(6 \mathrm{ekor} / \mathrm{m}^{2}\right)$ terlihat produksi dan sintasan udang paling tinggi serta konversi pakan paling rendah dibanding dengan perlakuan $\mathrm{A}$ (4 ekor/ $\left.\mathrm{m}^{2}\right)$ dan $\mathrm{C}\left(8 \mathrm{ekor} / \mathrm{m}^{2}\right)$.

Pada perlakuan $\mathrm{C}\left(8 \mathrm{ekor} / \mathrm{m}^{2}\right)$, walaupun tinggal satu petak, namun petak tersebut juga telah terserang WSSV dan udang telah mengalami kematian selama lima hari berturut-turut terutama udang yang ukurannya lebih besar dari ukuran rata-ratanya, sehingga yang dipanen pada hari ke- 91 hanya tinggal $4,9 \mathrm{~kg}$.

Hasil tersebut menunjukkan adanya kaitan antara padat tebar udang windu dalam tambak dengan intensitas serangan WSSV. Semakin padat populasi udang, kemungkinan terinfeksi WSSV akan lebih 
besar. Keadaan yang demikian kemungkinan ada kaitan dengan cemaran yang ditimbulkan baik dari sisa pakan ataupun feses udang, meskipun dalam penelitian ini telah menggunakan biota biofilter seperti tiram dan rumput laut, namun terlihat hanya efektif mampu mengurangi kandungan BOT di tambak tandon, sedangkan di tambak perlakuan kandungan BOT di ketiga perlakuan terus meningkat. Hal ini berarti bahwa volume penggantian air tambak perlakuan, frekuensi penggantiannya dengan air dari tandon, dan kecepatan sirkulasi masih perlu ditingkatkan, sehingga kandungan BOT di tambak perlakuan tidak meningkat terus.

Pada tambak dengan kepadatan udang lebih tinggi mestinya akan lebih banyak cemaran dibanding dengan tambak yang mempunyai padat tebar udang lebih rendah, sehingga virus, bakteri, dan jenis penyakit lainnya akan lebih cepat berkembang, namun berdasarkan uji statistik terhadap kandungan BOT dari tambak udang dengan padat tebar 4 (A), 6 (B), dan 8 ekor $/ \mathrm{m}^{2}(\mathrm{C})$ menunjukkan perbedaan yang tidak berarti $(P>0,05)$.

Fluktuasi kandungan BOT selama penelitian berlangsung dapat dilihat pada Gambar 2. Kandungan
BOT cenderung mengalami penurunan sampai penelitian berakhir terutama di tambak tandon, hal ini kemungkinan karena aktivitas tiram dan bandeng sebagai biofilter. Sedangkan di tambak perlakuan terdapat peningkatan BOT dimulai setelah pemberian pakan pada udang yaitu mulai pada hari ke-14 hingga hari ke-70 yaitu dari $8,8 \mathrm{mg} / \mathrm{L}$ meningkat menjadi 29,7 $\mathrm{mg} / \mathrm{L}\left(A=4\right.$ ekor $\left./ \mathrm{m}^{2}\right)$; dari $8,4 \mathrm{mg} / \mathrm{L}$ menjadi $29,8 \mathrm{mg} /$ $\mathrm{L}\left(\mathrm{B}=6 \mathrm{ekor} / \mathrm{m}^{2}\right) ;$ dan dari $9,2 \mathrm{mg} / \mathrm{L}$ menjadi $30,2 \mathrm{mg} /$ $\mathrm{L}\left(\mathrm{C}=8 \mathrm{ekor} / \mathrm{m}^{2}\right)$. Tingginya kandungan $\mathrm{BOT}$ di tambak perlakuan kemungkinan akibat penumpukan bahan organik sisa pakan dan sisa metabolisme dari udang yang dipelihara di tambak perlakuan $A, B$, maupun $C$

Salinitas pada kisaran 33-45 ppt; pH 8, 16-8,87; oksigen terlarut $5,14-6,42 \mathrm{mg} / \mathrm{L}$. Tingginya salinitas karena penelitian berlangsung pada saat musim kemarau, di mana penebaran benur dilakukan pada tanggal 10 Juni dan pemeliharaannya berlangsung hingga tanggal 10 September 2002. Pada perlakuan A $\left(4 \mathrm{ekor} / \mathrm{m}^{2}\right)$, walaupun masih terdapat dua ulangan tetapi produksi udang yang dipanen nampak rendah yaitu rata-rata hanya $11,5 \mathrm{~kg} / 500 \mathrm{~m}^{2}$ dan konversi pakan adalah 1,5:1; lebih tinggi dari perlakuan $B$ yaitu 1,3:1. Mangampa et al. (1994) mendapatkan konversi

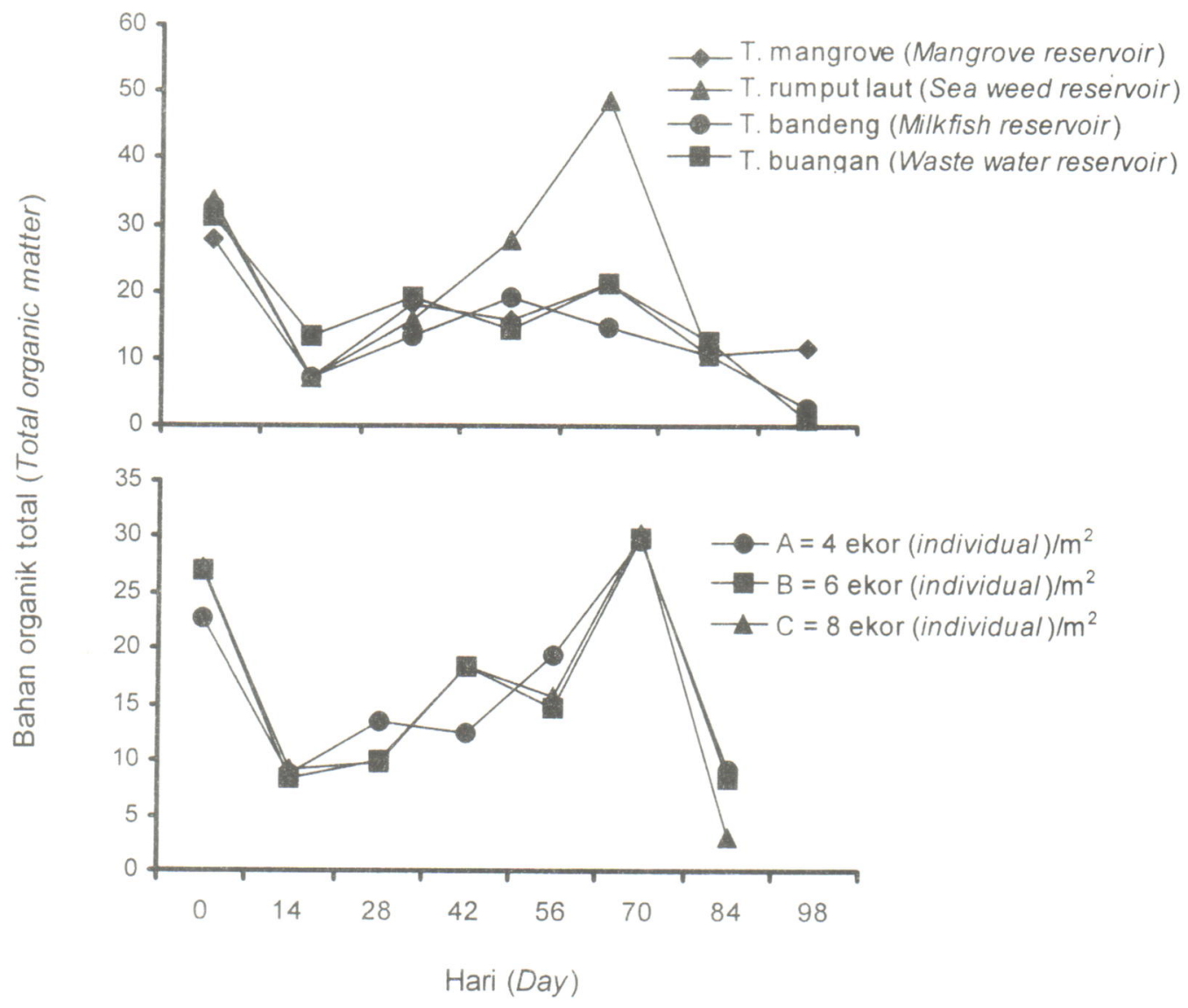

Gambar 2. Fluktuasi Bahan Organik Total (BOT) di tambak tandon dan di tambak perlakuan A, B, dan C Figure 2. Total Organic Matter (TOM) fluctuation in reservoir pond and treatment pond $A, B$, and $C$ 
Tabel 1. Parameter produksi dari udang yang dibudidayakan di tambak dengan padat tebar berbeda Table 1. Production parameters of cultured shrimp in brackishwater pond at the different stocking densities

\begin{tabular}{|c|c|c|c|}
\hline \multirow{2}{*}{$\begin{array}{l}\text { Faktor produksi } \\
\text { Production factors }\end{array}$} & \multicolumn{3}{|c|}{ Perlakuan (Treatments) } \\
\hline & A & B & C \\
\hline Ukuran tambak (Pond size) $\left(\mathrm{m}^{2}\right)$ & 500 & 500 & 500 \\
\hline Padat tebar (Stocking densities) (ind $/ \mathrm{m}^{2}$ ) & 4 & 6 & 8 \\
\hline Ukuran tebar (Stocking size) $(\mathrm{g})$ & $0.04 \pm 0.026$ & $0.04 \pm 0.051$ & $0.04 \pm 0.026$ \\
\hline Ukuran panen (Harvest size) $(\mathrm{g})$ & $\begin{array}{c}40--60 \text { ind. } / \mathrm{kg} \\
(53.7 \% \text { dari sampel } \\
(\text { from sample }))\end{array}$ & $\begin{array}{c}40-60 \text { ind } / \mathrm{kg} \\
(50.7 \% \text { dari sampel) } \\
\text { (from sample }))\end{array}$ & $>100$ ind. $/ \mathrm{kg}$ \\
\hline Sintasan (Survival rate) $(\%)$ & 53.2 & 58.1 & 22.8 \\
\hline Produksi udang (Shrimp production) $(\mathrm{kg})$ & 12.4 & 20.8 & 4.9 \\
\hline Konversi pakan (Feed convertion) & 1.5 & 1.3 & $>3$ \\
\hline
\end{tabular}

pakan antara 1,29-1,51 pada budi daya udang intensif menggunakan benur yang dibantut terlebih dahulu pada pemeliharaan udang di tambak dengan salinitas pada kisaran 5-20 ppt. Sedangkan pada penelitian ini salinitas telah mencapai $33-45$ ppt, sehingga walaupun konversi pakan rendah, tetapi ukuran udang yang dipanen setelah umur pemeliharaan 91 hari masih kecil-kecil yaitu antara 40-90 ekor/kg (perlakuan A dan B) sehingga jumlah panenan menjadi sedikit. Hal ini karena pertumbuhan udang lambat akibat salinitas yang tinggi. Pendapat ini telah didukung oleh hasil penelitian Suwirya et al. (1986) yang mengatakan bahwa pertumbuhan udang windu pada salinitas 31--32 ppt lebih rendah secara nyata $(P<0,05)$ bila dibandingkan dengan pertumbuhannya pada salinitas $17-20 \mathrm{ppt}$ dan $12-15 \mathrm{ppt}$. Selanjutnya Poernomo (1978) mengemukakan bahwa udang windu tumbuh baik apabila kadar garamnya pada level yang optimal untuk pertumbuhannya yaitu $15-25 \mathrm{ppt}$. Hal ini karena transformasi energi lebih banyak digunakan untuk proses pembentukan daging dan hanya sedikit energi yang digunakan untuk proses osmoregulasi dalam usaha menjaga keseimbangan tekanan cairan tubuh dengan lingkungannya. Menurut Chanratchakool et al. (1995), salinitas antara 10-30 ppt telah direkomendasikan untuk pemeliharaan udang windu di tambak, namun karena alasan non teknis sehingga pelaksanaan penelitian ini selalu menjadi mundur dan pada akhirnya mendapatkan salinitas yang kurang ideal bagi pertumbuhan udang. Walaupun demikian analisis regressi untuk melihat hubungan antara salinitas dengan pertumbuhan udang menunjukkan nilai $r=0,95(A) ; 0,95(B)$; dan 0,93 (C). Dengan demikian meskipun salinitas semakin tinggi hingga mencapai $45 \mathrm{ppt}$, tetapi pertumbuhan udang windu di tambak tetap berlangsung meskipun lambat.

Kandungan fosfat relatif sama fluktuasinya baik di tambak tandon maupun di tambak perlakuan
(Gambar 3). Fosfat merupakan bentuk fosfor yang dapat dimanfaatkan oleh tumbuhan tingkat tinggi maupun alga, sehingga unsur tersebut menjadi faktor pembatas bagi tumbuhan akuatik dan alga serta sangat mempengaruhi tingkat produktivitas perairan.

Pada hari ke- 1 hingga hari ke- 42 kandungan fosfat cukup yaitu $0,58 \mathrm{mg} / \mathrm{L}$ di tambak tandon bakau. Namun setelah hari ke-42 hingga hari ke- 84 kandungan fosfat terjadi fluktuasi cukup tinggi baik di tambak tandon maupun di tambak perlakuan yaitu pada kisaran $0,12-1,9 \mathrm{mg} / \mathrm{L}\left(\mathrm{A}=4 \mathrm{ekor} / \mathrm{m}^{2}\right) ; 0,14-2,1 \mathrm{mg} / \mathrm{L}(\mathrm{B}=$ 6 ekor $\left./ \mathrm{m}^{2}\right)$; dan $0,12-2,0 \mathrm{mg} / \mathrm{L}\left(\mathrm{C}=8 \mathrm{ekor} / \mathrm{m}^{2}\right)$ dan rata-ratanya menunjukkan perbedaan yang tidak nyata $(P>0,05)$ di antara ketiga perlakuan tersebut. Menurut Choo \& Tanaka (2000), bahwa kadar fosfat yang direkomendasikan supaya tidak terjadi eutrofikasi di pantai dan laut adalah $0,0045 \mathrm{mg} / \mathrm{L}$ dan $0,0015 \mathrm{mg} / \mathrm{L}$. Dengan demikian konsentrasi fosfat di tambak jauh melebihi konsentrasi fosfat yang direkomendasikan di perairan pantai dan hal ini jelas dapat menyebabkan eutrofikasi apabila air tambak dibuang terutama pada saat ganti air ataupun panen.

Hubungan antara kandungan fosfat dengan populasi fitoplankton menunjukkan bahwa pada awal penelitian berlangsung, konsentrasi fosfat relatif tinggi di semua perlakuan yaitu $0,77 \mathrm{mg} / \mathrm{L}\left(A=4 \mathrm{ekor} / \mathrm{m}^{2}\right)$; $0,68 \mathrm{mg} / \mathrm{L}\left(\mathrm{B}=6 \mathrm{ekor} / \mathrm{m}^{2}\right) ;$ dan $0,92 \mathrm{mg} / \mathrm{L}(\mathrm{C}=8$ ekor/ $\mathrm{m}^{2}$ ) dengan kepadatan fitoplankton sebanyak 127.000 sel/L (A), $167.000 \mathrm{sel} / \mathrm{L}$ (B), dan $445.000 \mathrm{sel} . / \mathrm{L}$ (C) Sedangkan pada akhir penelitian konsentrasi fosfat semakin tinggi di semua tambak perlakuan yaitu 1,6 $\mathrm{mg} / \mathrm{L}\left(\mathrm{A}=4\right.$ ekor $\left./ \mathrm{m}^{2}\right), 1,7 \mathrm{mg} / \mathrm{L}\left(6\right.$ ekor $\left./ \mathrm{m}^{2}\right) ;$ dan 1,5 $\mathrm{mg} / \mathrm{L}\left(8 \mathrm{ekor} / \mathrm{m}^{2}\right)$ dengan kepadatan fitoplankton masing-masing $440.000 \mathrm{sel} / \mathrm{L}(\mathrm{A}), 430.000 \mathrm{sel} / \mathrm{L}(\mathrm{B})$; dan $565.000 \mathrm{sel} / \mathrm{L}(\mathrm{C})$. Sedangkan nilai $r=0,43(\mathrm{~A})$, $r=-0,41(B)$; dan $r=-0,29(C)$, dengan demikian dapat dikatakan bahwa peningkatan kandungan fosfat dapat meningkatkan populasi fitoplankton. 


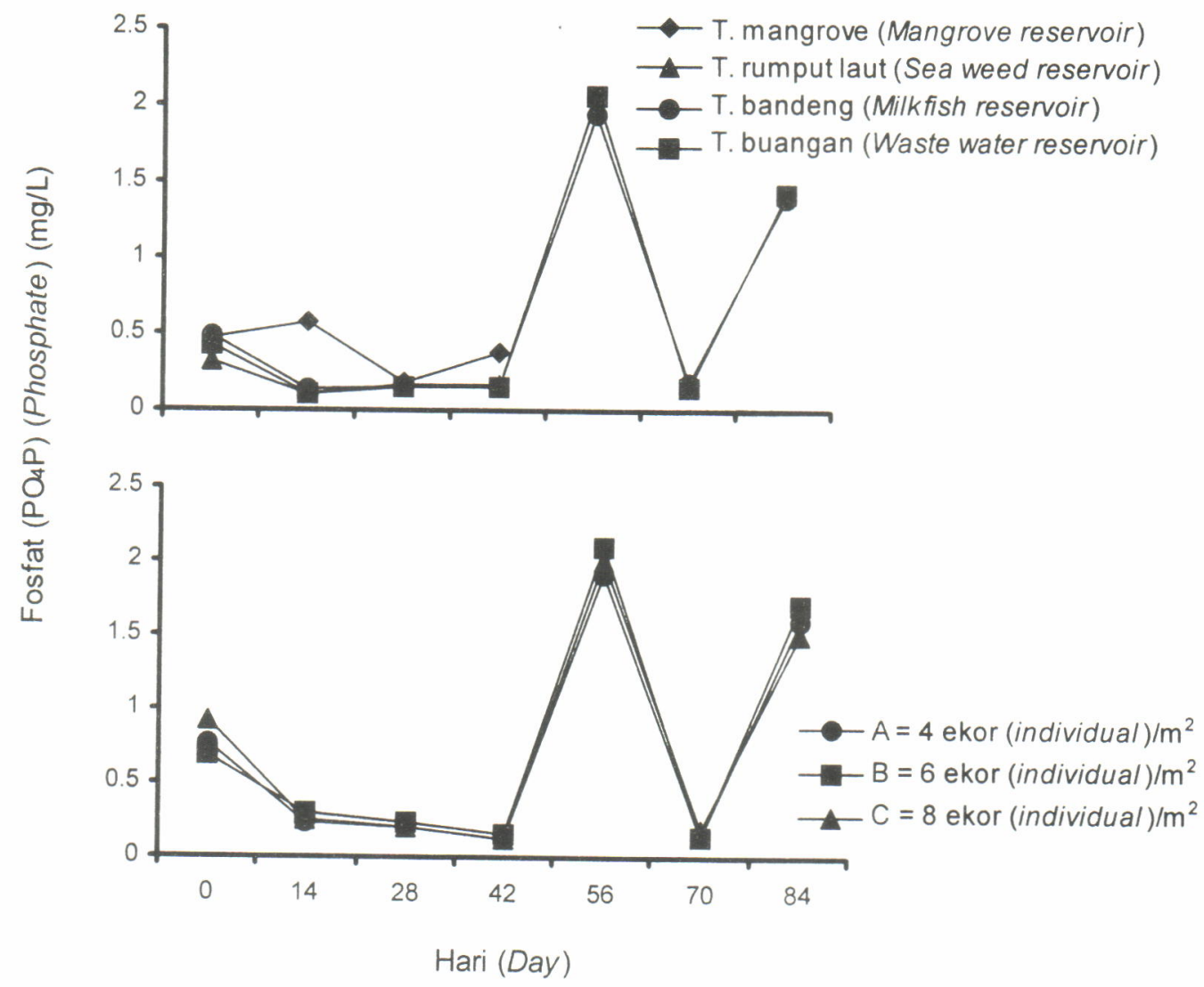

Gambar 3. Fluktuasi fosfat di tambak tandon dan tambak perlakuan A, B, dan C

Figure 3. Phosphate fluctuation in reservoir and treatment pond $A, B$, and $C$

Kandungan amonia baik di tambak tandon maupun di tambak perlakuan cukup tinggi di awal penelitian, hal ini karena bahan organik total pada awalnya juga tinggi baik di tambak tandon maupun tambak perlakuan. Effendi (2003) melaporkan bahwa sumber amonia di perairan berasal dari pemecahan nitrogen organik (protein dan urea) dan nitrogen anorganik yang berasal dari dekomposisi bahan organik seperti tumbuhan dan organisme akuatik yang telah mati yang mengalami proses amonifikasi. Pada samplingsampling selanjutnya terdapat kecenderungan penurunan amonia baik di air tambak tandon dan di air tambak perlakuan (Gambar 4a). Pada hari ke 28 hingga hari ke-70 kandungan amonia nilai rata-ratanya menurun yaitu dari 0,51 turun menjadi $0,007 \mathrm{mg} / \mathrm{L}$ $\left(A=4 \mathrm{ekor} / \mathrm{m}^{2}\right)$, dari 0,49 turun menjadi $0,009 \mathrm{mg} / \mathrm{L}$ $\left(B=6 \mathrm{ekor} / \mathrm{m}^{2}\right)$ dan dari 0,58 turun menjadi $0,01 \mathrm{mg} / \mathrm{L}$ $\left(\mathrm{C}=8 \mathrm{ekor} / \mathrm{m}^{2}\right)$. Penurunan tersebut kemungkinan akibat proses perombakannya menjadi nitrit pada periode tersebut berlangsung lebih cepat, sehingga amonia tidak sampai terakumulasi dalam perairan tambak. Proses nitrifikasi tersebut dengan bantuan bakteri Nitrosomonas sp. dan selanjutnya nitrit dirombak menjadi nitrat dengan bantuan bakteri Nitrobacter $\mathrm{sp}$.
Kondisi optimal untuk kedua proses tersebut adalah apabila jumlah oksigen mencukupi, kapasitas buffer baik, $\mathrm{pH}$ netral, dan suhu air rendah. Pada penelitian ini di tambak perlakuan, suhu pada kisaran $27^{\circ} \mathrm{C}-29,7^{\circ} \mathrm{C}$; oksigen terlarut berkisar antara 4,55 $6,61 \mathrm{mg} / \mathrm{L}, \mathrm{pH} 8,33-8,65$; alkalinitas 55,66-83,49 $\mathrm{mg} / \mathrm{L}$. Pada hari ke-56 kandungan nitrit cukup tinggi baik di tambak tandon maupun tambak perlakuan (Gambar 4b). Menurut Boyd (1990), kandungan nitrit yang aman di tambak pembesaran benur udang windu adalah 4,5 mg/L dan konsentrasi amonia 0,45 mg/L sudah dapat mengurangi laju tumbuh udang sebanyak $50 \%$. Sedangkan menurut Puryaningsih (2003), kandungan nitrit di air tambak harus lebih kecil dari $0,01 \mathrm{mg} / \mathrm{L}$ dan amonium harus lebih kecil dari 1 $\mathrm{mg} / \mathrm{L}$.

Kandungan nitrat mempunyai pola yang sama di semua petak tandon dan berfluktuasi yaitu dari 0,55 $\mathrm{mg} / \mathrm{L}$ hingga ke $0,05 \mathrm{mg} / \mathrm{L}$. Pada akhir penelitian di air petak tandon kandungan nitrat pada kisaran 0,35$0,40 \mathrm{mg} / \mathrm{L}$; sedangkan di air tambak perlakuan cenderung menurun dari awal penelitian hingga akhir penelitian yaitu dari $0,70-1,0 \mathrm{mg} / \mathrm{L}$ turun hingga 0,3 $\mathrm{mg} / \mathrm{L}$ (Gambar 4C). Begitu juga kandungan nitrat di air tambak tandon puncaknya terjadi pada hari ke-42 
hingga 56. Sedangkan di air tambak periakuan pada periode tersebut nitrat kemungkinan telah banyak dimanfaatkan oleh fitoplankton, sehingga kandungan nitrat di air tambak perlakuan lebih rendah daripada di air tambak tandon. Tsai \& Chen (2002) melaporkan bahwa konsentrasi nitrat yang masih diterima dalam kegiatan budi daya perikanan adalah kurang dari 20 $\mathrm{mg} / \mathrm{L}$. Sedangkan menurut Effendi (2003), kadar nitratnitrogen lebih dari $0,2 \mathrm{mg} / \mathrm{L}$ dapat mengakibatkan terjadinya eutrofikasi (pengkayaan nutrien) di perairan yang selanjutnya dapat menstimulir pertumbuhan alga dan tumbuhan air secara cepat.

\section{Indeks Keragaman Fitoplankton}

Indeks keragaman plankton digunakan untuk melihat keseimbangan dan tingginya keragaman populasi plankton di suatu perairan. Pada perairan yang mempunyai keragaman fitoplankton tinggi dan populasinya mendekati seimbang, maka nilai indeks

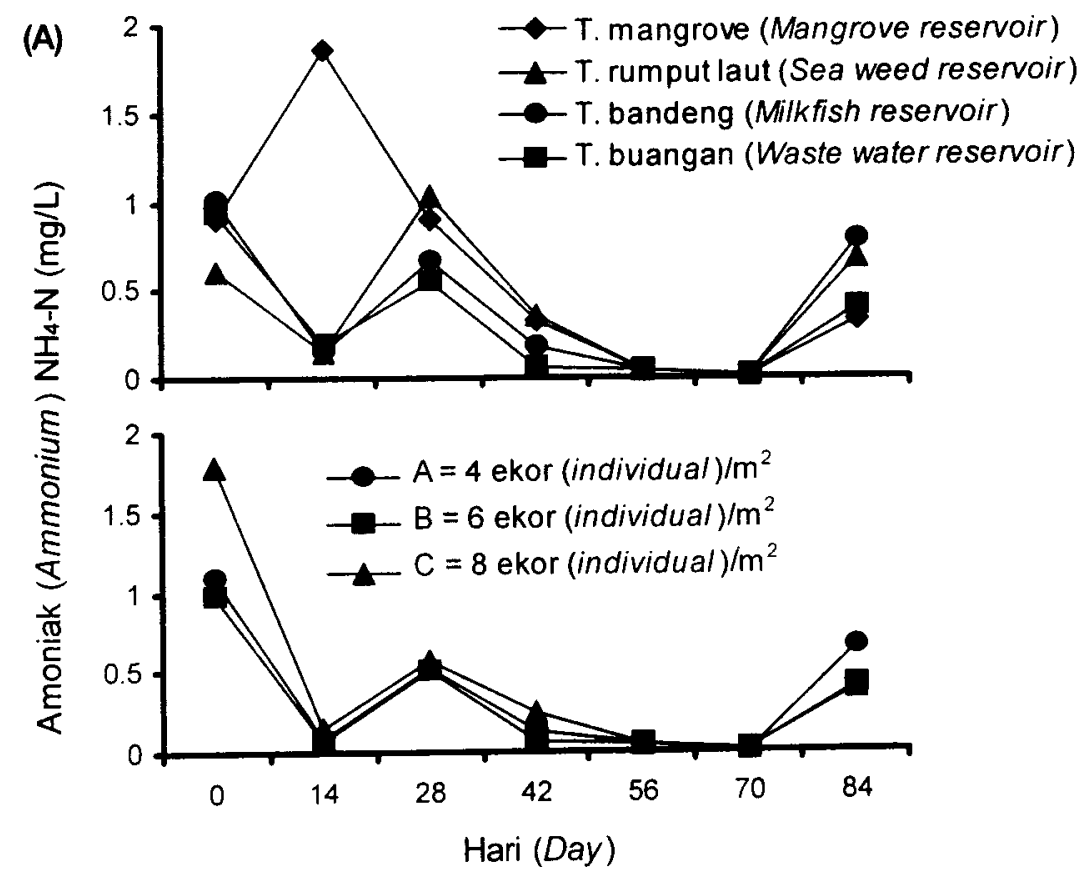

(B)

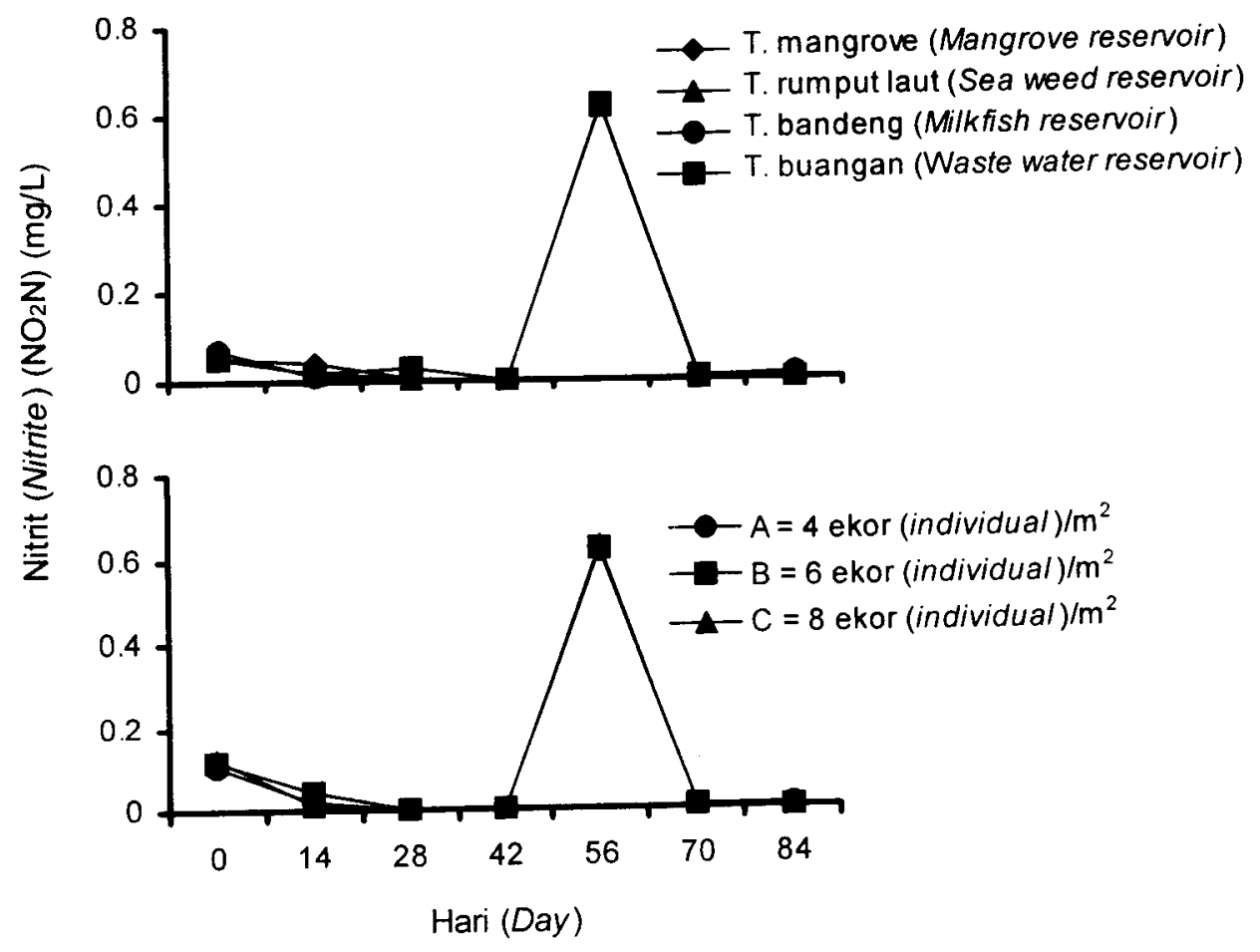




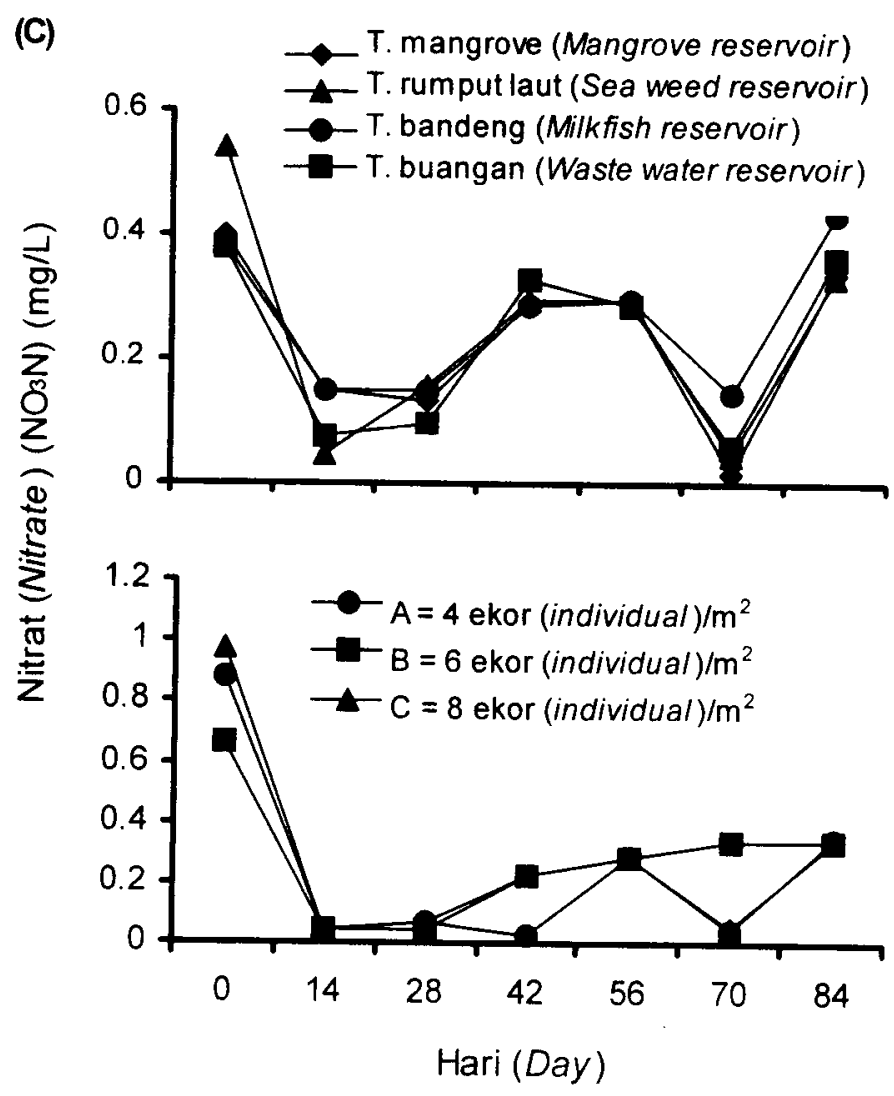

Gambar 4. Fluktuasi amonia (a), nitrit (b), dan nitrat (c) di tambak tandon dan tambak Perlakuan A, B, dan C Figure 4. Ammonium (a), nitrite (b), and nitrate (c) fluctuation in pond resenoir and treatment pond $A, B$, and $C$

keragaman mendekati 1,0 yang berarti bahwa perairan tersebut semakin stabil. Sedangkan perairan dengan keragaman rendah atau keseimbangan populasi rendah, maka nilai indeks keragaman akan rendah mendekati angka 0 yang berarti bahwa perairan tersebut kurang stabil (Williams, 1987).

Indeks keragaman fitoplankton pada tambak budi daya udang menggunakan teknologi semi tertutup dengan padat tebar berbeda menunjukkan puncakpuncak indeks keragaman fitoplankton agak tinggi (Gambar 5). Di tambak perlakuan A, padat tebar 4 ekor $/ \mathrm{m}^{2}$ terdapat satu puncak yaitu pada hari ke- 42 $(0,38)$. Di tambak perlakuan B, padat tebar $6 \mathrm{ekor} / \mathrm{m}^{2}$ terdapat tiga puncak yaitu pada awal penelitian $(0,40)$; hari ke-42 $(0,59)$; dan hari ke- $75(0,39)$, sedangkan di perlakuan $\mathrm{C}$, padat tebar $8 \mathrm{ekor} / \mathrm{m}^{2}$ terdapat dua kali

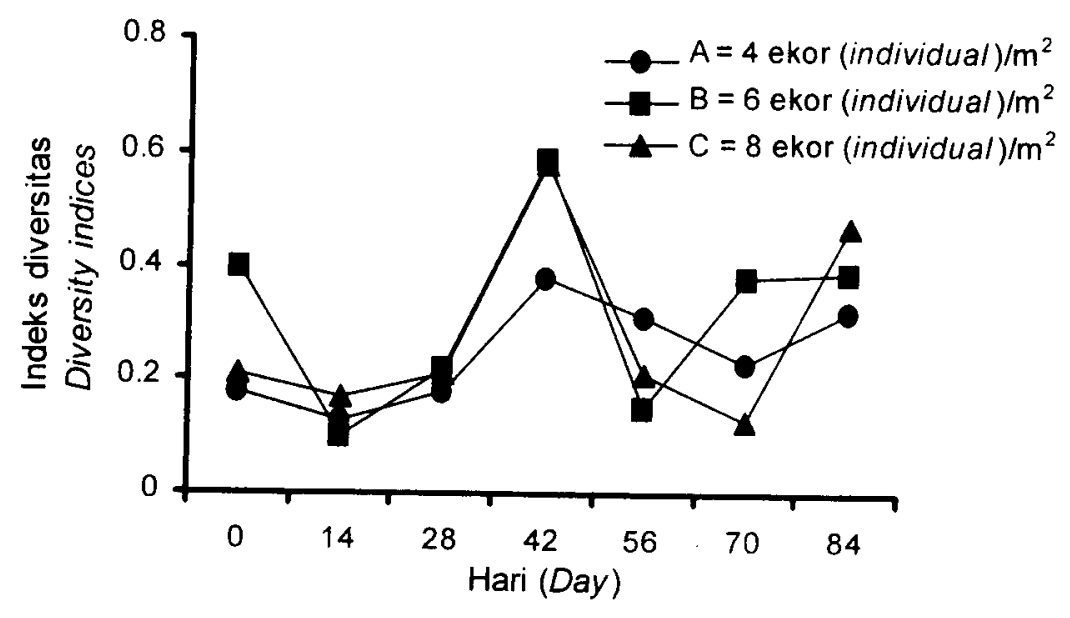

Gambar 5. Nilai indeks keragaman fitoplankton di tambak perlakuan Figure 5. Value of phytoplankton diversity indices in treatment pond 
puncak yaitu pada hari ke-42 $(0,58)$ dan ke-84 $(0,40)$. Fitoplankton yang selalu mendominasi di semua petak tambak selama penelitian adalah Nitzschia longisima. Sedangkan zooplankton kepadatan dan keragamannya tinggi hanya terjadi pada dua minggu pertama yang didominasi oleh Brachionus urceolaris. Sedangkan pada minggu-minggu berikutnya populasi dan keragaman zooplankton menurun sampai berakhir penelitian.

\section{Populasi Bakteri}

\section{Bakteri di air}

Populasi bakteri Vibrio sp. di air tandon bakau menurun dari $2,96 \times 10^{2} \mathrm{CFU} / \mathrm{mL}$ menjadi $1,78 \times 10^{2}$ $\mathrm{CFU} / \mathrm{mL}$. Di tandon rumput laut dan tandon bandeng populasi bakteri juga menurun yaitu masing-masing dari $2,7 \times 10^{2} \mathrm{CFU} / \mathrm{mL}$ menjadi $2,2 \times 10^{2} \mathrm{CFU} / \mathrm{mL}$ dan dari $2,9 \times 10^{2} \mathrm{CFU} / \mathrm{mL}$ menjadi $2,2 \times 10^{2} \mathrm{CFU} / \mathrm{mL}$. Di sungai populasi bakteri menurun yaitu $2,9 \times 10^{2} \mathrm{CFU} /$ $\mathrm{mL}$ turun menjadi $2,6 \times 10^{2} \mathrm{CFU} / \mathrm{mL}$. Sedangkan di air tandon pembuangan populasi bakteri nampak meningkat yaitu dari $2,3 \times 10^{2} \mathrm{CFU} / \mathrm{mL}$ menjadi $3,2 \times$ $10^{2} \mathrm{CFU} / \mathrm{mL}$.

Populasi bakteri di air tambak perlakuan menunjukkan peningkatan populasi. Hal ini kemungkinan akibat pengaruh akumulasi bahan organik yang mampu meningkatkan populasi bakteri Vibrio sp. di air tambak. Di air tambak perlakuan A (4 ekor $/ \mathrm{m}^{2}$ ) populasi bakteri meningkat dari $1,9 \times 10^{2}$ $\mathrm{CFU} / \mathrm{mL}$ menjadi $2,9 \times 10^{2} \mathrm{CFU} / \mathrm{mL}$; di air tambak perlakuan $\mathrm{B}\left(6 \mathrm{ekor} / \mathrm{m}^{2}\right)$ dari $2,4 \times 10^{2} \mathrm{CFU} / \mathrm{mL}$ menjadi $2,9 \times 10^{2} \mathrm{CFU} / \mathrm{mL}$; dan di air tambak perlakuan C (8 ekor $/ \mathrm{m}^{2}$ ) dari $2,2 \times 10^{2} \mathrm{CFU} / \mathrm{mL}$ menjadi $3,3 \times 10^{2}$ CFU/mL (Gambar 6).
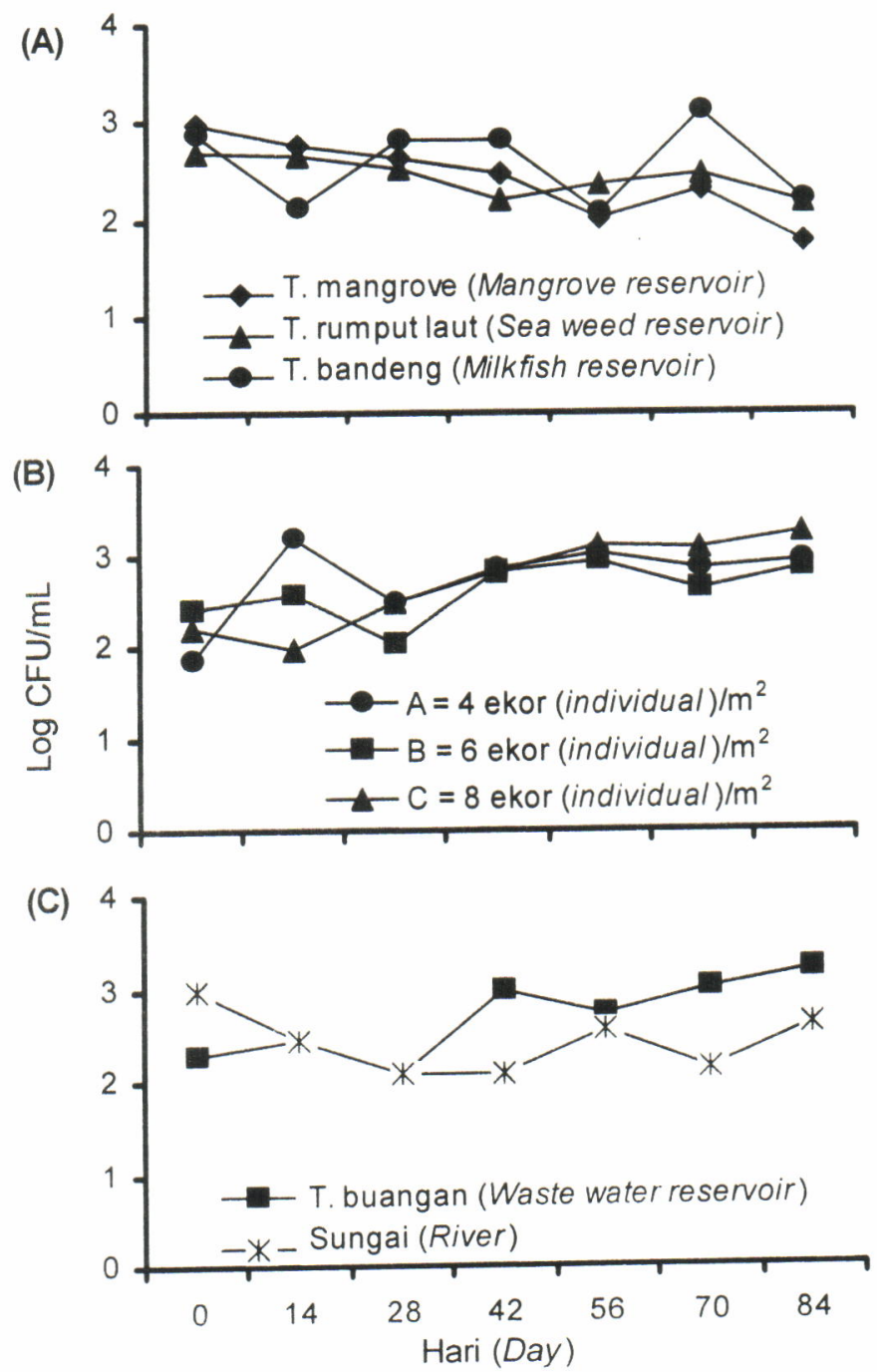

Gambar 6. Populasi bakteri Vibrio sp. di air tambak tandon (a), tambak perlakuan (b), tandon pembuangan, dan sungai (c)

Figure 6. Vibrio sp. bacterial population in waters of reservoir pond (a), treatment pond (b), waste water reservoir, and river (c) 
Ternyata penurunan populasi bakteri hanya terjadi di air dari semua tambak tandon. Hal ini membuktikan bahwa tandon bekerja efektif tidak hanya menurunkan BOT tetapi juga kandungan total bakteri Vibrio sp. Hal ini sesuai hasil penelitian Gunarto et al. (2002). Ahmad (1999) menyatakan bahwa bakau mampu meredam perkembangan populasi Vibrio $\mathrm{sp}$. kemungkinan karena adanya kandungan tannin. Sedangkan menurut Suryati et al. (2001) zat bioaktif yang terkandung dalam tanaman bakau mampu menghambat pertumbuhan populasi bakteri Vibrio harveyi.

\section{Bakteri di Sedimen}

Bakteri sedimen tanah tambak ternyata konsentrasinya selalu lebih tinggi daripada konsentrasi bakteri air tambak, saluran dan sungai. Di sedimen tandon bakau, tandon rumput laut, dan tandon bandeng terjadi peningkatan populasi dari awal penelitian hingga hari ke-84 pemeliharaan udang di tambak yaitu masing-masing berturut-turut dari $3,2 x$ $10^{3} \mathrm{CFU} / \mathrm{mL}$ naik menjadi $4,2 \times 10^{3} \mathrm{CFU} / \mathrm{mL}$; dari 2,7 $\times 10^{3} \mathrm{CFU} / \mathrm{mL}$ menjadi $4,1 \times 10^{3} \mathrm{CFU} / \mathrm{mL}$; dan dari $3,7 \times 10^{3} \mathrm{CFU} / \mathrm{mL}$ menjadi $4,5 \times 10^{3} \mathrm{CFU} / \mathrm{mL}$ (Gambar 7a). Peningkatan tertinggi terjadi di sedimen tandon bandeng, kemudian disusul pada sedimen tandon bakau dan sedimen tandon rumput laut. Pada sedimen sungai dan sedimen tandon pembuangan juga terjadi peningkatan populasi bakteri, yaitu masing-masing dari $3,2 \times 10^{3} \mathrm{CFU} / \mathrm{mL}$ menjadi $3,5 \mathrm{x}$ $10^{3} \mathrm{CFU} / \mathrm{mL}$ dan dari $3,2 \times 10^{3} \mathrm{CFU} / \mathrm{mL}$ menjadi $3,5 \times$ $10^{3} \mathrm{CFU} / \mathrm{mL}$ (Gambar 7c). Pada sedimen tambak perlakuan, nampak populasi bakteri relatif stabil yaitu
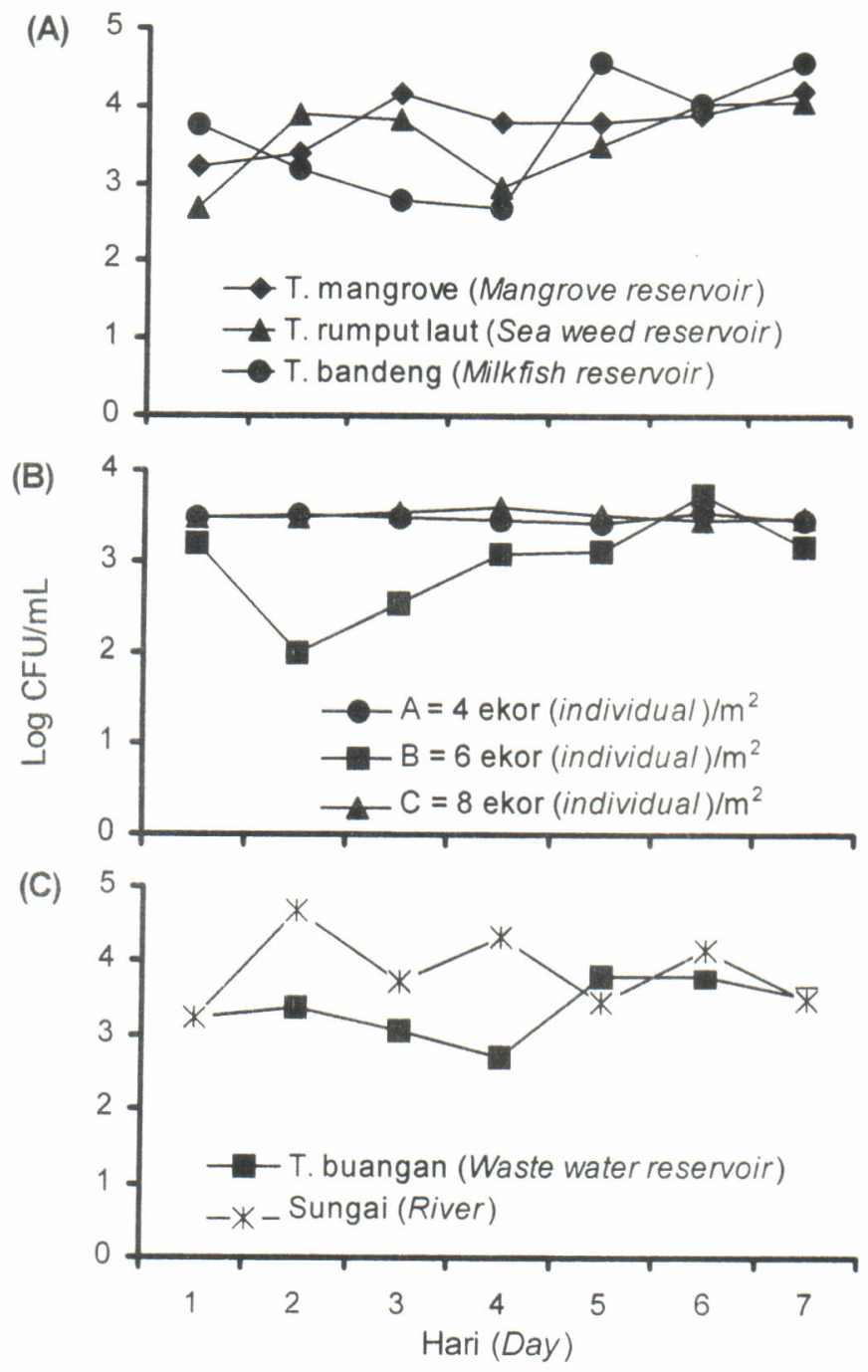

Gambar 7. Populasi bakteri Vibrio sp. di sedimen tambak tandon (a), tambak perlakuan (b), tandon pembuangan dan sungai (c)

Figure 7. Vibrio sp. bacterial population in sediment of reservoir pond (a), treatment pond (b), waste water resenvoir and river (c) 
masing-masing berturut-turut dari $3,5 \times 10^{3} \mathrm{CFU} / \mathrm{mL}$ menjadi $3,4 \times 10^{3} \mathrm{CFU} / \mathrm{mL}$ (tambak perlakuan $\mathrm{A}$ ); dari $3,2 \times 10^{3} \mathrm{CFU} / \mathrm{mL}$ menjadi $3,1 \times 10^{3} \mathrm{CFU} / \mathrm{mL}$ (tambak perlakuan $\mathrm{B}$ ); dan dari $3,5 \times 10^{3} \mathrm{CFU} / \mathrm{mL}$ tetap dengan konsentrasi 3,5 $\times 10^{3} \mathrm{CFU} / \mathrm{mL}$ (tambak perlakuan C) (Gambar 7b). Mengapa populasi bakteri di sedimen tambak perlakuan tidak terjadi peningkatan, padahal bahan organik jelas terjadi peningkatan yaitu yang berasal dari sisa pakan dan kotoran udang. Menurut Brock et al. (1994), peningkatan konsentrasi nutrien selalu akan terus mampu meningkatkan populasi bakteri, tetapi apabila nutrien telah mengalami kejenuhan di sedimen, seperti yang terjadi dalam perlakuan dalam penelitian ini, maka populasi total Vibrio sp. tidak mengalami peningkatan.

\section{KESIMPULAN}

Kualitas air tambak menggunakan pola resirkulasi dengan sistem tandon dan penggantian air $1-2$ kali pada setiap periode pasang sebanyak $10 \%-15 \%$ dari total volume air tambak, ternyata belum mampu mengurangi peningkatan kandungan BOT tambak udang sebagai akibat timbunan sisa pakan dan sisa metabolisme dari udang yang dipelihara.

Tiram dan bandeng sebagai hewan biofilter mampu menurunkan kandungan BOT dan total bakteri Vibrio sp. pada semua air tambak tandon, tetapi dalam air tambak perlakuan masih terdapat kecenderungan peningkatan kandungan bakteri Vibrio sp.

Puncak-puncak keragaman fitoplankton agak tinggi yang berarti bahwa kondisi perairan agak stabil, pada kepadatan udang 4 ekor $/ \mathrm{m}^{2}$ (perlakuan A) terjadi sekali yaitu pada hari ke-42 $(0,38)$, pada kepadatan 6 ekor/ $\mathrm{m}^{2}$ (perlakuan $\mathrm{B}$ ) terjadi tiga kali yaitu pada awal penelitian $(0,40)$, hari ke-42 $(0,59)$, dan hari ke-75 $(0,39)$, sedangkan pada kepadatan $8 \mathrm{ekor} / \mathrm{m}^{2}$ (perlakuan C) terjadi dua kali yaitu pada hari ke-42 $(0,58)$ dan ke-84 $(0,40)$. Dari hasil ini nampak ada korelasi antara produksi udang dengan kestabilan perairan tambak.

Berdasarkan produksi, sintasan, dan konversi pakan udang setelah 91 hari pemeliharaan di tambak, maka padat tebar yang optimum adalah 6 ekor $/ \mathrm{m}^{2}$.

\section{SARAN}

Agar kandungan BOT air tambak berkurang lebih signifikan, maka dalam operasional budi daya udang dengan padat tebar $4-8$ ekor $/ \mathrm{m}^{2}$, frekuensi penggantian air tambak jangan hanya $1-2$ kali setiap periode air pasang, tetapi hendaklah ditingkatkan menjadi 3-4 kali dan volume penggantian air sebanyak $10 \%-5 \%$ dari total volume air dalam tambak.

\section{DAFTAR PUSTAKA}

Ahmad, T. 1999. Pemanfaatan mangrove sebagai biofilter dan bioremediator budidaya udang. Makalah disampaikan dalam Rapat Kerja Teknis dan Pembahasan Hasil-Hasil Penelitian T.A. 1998/1999, Balai Penelitian Perikanan Pantai, 16 pp.

Atmomarsono, M., Muliani, dan S. Ismawati. 1995. Prospek penggunaan tandon pada budidaya udang windu. Makalah disajikan pada Aplikasi Paket Teknologi di Instalasi Penelitian dan Pengkajian Teknologi Pertanian (IPPTP) Wonocolo, Surabaya 2-4 Juli 1995, $10 \mathrm{pp}$.

Atmomarsono. 2003. Upaya penanggulangan penyakit udang windu secara utuh dan terpadu. Makalah disampaikan pada acara Temu Konsultasi dan Sosialisasi Teknologi Budidaya Udang Ramah Lingkungan di Balai Riset Perikanan Budidaya Air Payau Maros, 9-10 Juli 2003, 10 pp.

Boyd, C.F. 1990. Water Quality in Ponds for Aquaculture. Auburn University, Alabama USA, 482 pp.

Brock, T.D., M.T. Madigan, J.M. Martinko, dan J. Parker. 1994. Biology of Microorganisme. $7^{\text {nd }}$ Prentice-Hall International, Inc., p. 321-329.

Chanratchakool, P.J.F. Turnbull, S. Funge-Smite, dan C. Limsuwan. 1995. Health Management in Shrimp Ponds. $2^{\text {nd }}$ Ed. Aquatic Animal Health Research Institute. Department of Fisheries, Kasetsat University Campus, Jatyujak, Thailand, $100 \mathrm{pp}$.

Choo, P.S. dan K. Tanaka. 2000. Nutrient levels in ponds during the grow-out and harvest phase of Penaeus monodon under semi-intensive or intensive culture. JIRCAS Journal, (8): 13-20.

Effendi, H. 2003. Telaah Kualitas Air bagi Pengelolaan Sumber Daya dan Lingkungan Perairan. Kanisius Yogyakarta, $258 \mathrm{pp}$.

Gunarto, Suharyanto, Muslimin, dan A.M. Tangko. 2003. Budidaya udang windu menggunakan tandon mangrove dengan pola resirkulasi berbeda. J. Pen. Per. Indonesia, edisi Akuakultur, 9(2): 57-64.

Gunarto, Suharyanto, Muslimin, A.M. Tangko, A. Mansyur, M. Mangampa, M. Atmomarsono, dan R. Pasande. Pemanfaatan jamak tandon mangrove dalam budidaya udang windu di tambak. Laporan Penelitian Balai Penelitian Perikanan Pantai, 27 pp.

Isamu Yama. 1966. Illustration of the Marine Plankton of Japan. Hoikusha Publishing Co. Ltd. Osaka Japan, $369 \mathrm{pp}$.

Imai, T. 1971. Aquaculture in Shallow Seas: Progress in Shallow Seas Culture. National Technical Information. Service PB 280493 T., p. 151-192.

Mangampa, M. dan A. Mustafa. 1992. Budidaya udang windu, Penaeus monodon pada padat penebaran yang berbeda dengan menggunakan benih yang dibantut. J. Pen. Bud. Pantai, 8 (4): 37-48.

Mangampa, M., N. Kabangnga, A. Mustafa, dan M. Tjaronge. 1994. Budidaya udang windu Penaeus monodon secara intensif menggunakan benih yang dibantut dalam wadah yang berbeda. J. Pen. Bud. Pantai, (10) 5: 89-96. 
Mangampa, M., Burhanuddin, M. Tjaronge, dan Muliani. 1997. Pengaruh ukuran cangkang dan kepadatan kerang bakau, Geloina coaxan terhadap perbaikan mutu lingkungan tambak. Laporan Hasil Penelitian, Balai Penelitian Perikanan Pantai Maros, $7 \mathrm{pp}$.

Mangampa, M. 1998. Frekuensi pergantian biofilter tiram dalam tandon budidaya udang intensif Laporan Hasil Penelitian, Balai Penelitian Perikanan Pantai Maros, $7 \mathrm{pp}$.

Newel, G.E. dan R.C. Newel. 1987. Marine Plankton a Practical Guide. Huchinson \& Co (Publishers) Ltd, 243 pp.

Neori, A., M.D. Krom, S.P. Ellner, C.E. Boyd, D. Popper, R. Rabinovitch, P.J. Davison, O. Dvir, D. Zuber, M. Ucko, D. Angel, and H. Gordin. 1996. Seaweed biofilters as rogulators of water quality in integrated fish-seaweed culture units. Aquaculture, 141: 183-199.

Odum, E.P. 1963. Ecology. Second Edition. Holt, Rinehart and Winston, Inc All Rights Reserve, 243 pp.

Poernomo, A. 1978. Masalah udang penaeid di Indonesia. Simposium Modernisasi Perikanan Rakyat, Jakarta, 27 pp.

Parsons, R., Y. Maita, dan C.M. Lalli. 1984. A Manual of Chemical and Biological Methods for Seawater Analysis. Pergamon Press. Oxford, 173 pp.

Puryaningsih, E. 2003. Parameter-parameter penting di tambak. Untuk aplikasi tambak, Aqua Merck, 16 pp.
Suryati, E., Gunarto, dan Sulaeman. 2001. Analisis bioaktif tanaman mangrove yang efektif mereduksi penyakit bakteri pada budidaya udang windu. Makalah dipresentasikan pada Ekspose Hasil Penelitian Unggulan Pusat Riset Perikanan Budidaya, T.A. 2001. Pusat Riset Perikanan Budidaya, Jakarta, $10 \mathrm{pp}$.

Suwirya, K., Z.I. Azwar, dan T. Rochimat. 1986. Pemeliharaan benur windu Penaeus monodon dengan berbagai tingkat kadar garam dalam kondisi laboratorium. Jur. Pen. Bud. Pantai, (2)1: 34-39.

Scheefler, W.C. 1987. Statistika untuk Biologi, Farmasi Kedokteran, dan IImu yang Bertautan. ITB Bandung, p. 126--147.

Troell, M., P. Ronnback, C. Halling, N. Kautsky, dan A. Buschmann. 1999. Use of seaweeds for removing nutrients from intensive mariculture. J. Appl. Phycology, 11(1): 89-97.

Tsai, S.J. dan J.C. Chen. 2002. Acute toxicity of nitrate on Penaeus monodon juveniles at different salinity levels. Aquaculture, 213: 163-170.

Walne, P.R. 1972. The influence of current speed, body size and water temperature on the filtration rate of five species of bivalves. J. Mar. Biol. Ass. U.K, (52): 345-374.

Williams, G. 1987. Techniques and Fieldwork in Ecology. Bell and Hyman Limited, London, 125 pp. 